\title{
Group II intron from Pseudomonas alcaligenes NCIB 9867 (P25X) : entrapment in plasmid RP4 and sequence analysis
}

\author{
Chew Chieng Yeo, ${ }^{1}$ Jill Maelan Tham, ${ }^{2}$ Melvyn Wee-Ching Yap ${ }^{2}+$ and \\ Chit Laa Poh ${ }^{1,2}$
}

\author{
Author for correspondence: Chit Laa Poh. Tel: +65 772 3674. Fax: +65 7766872. \\ e-mail: micyeocc@nus.sg
}

Department of

Microbiology, Faculty of Medicine, ${ }^{1}$ and Bioscience Centre, School of Biological Sciences, 2 National University of Singapore, Lower Kent Ridge Road, Singapore 119260

\begin{abstract}
Pseudomonas alcaligenes NCIB 9867 (strain P25X), which grows on 2,5-xylenol and harbours the plasmid RP4, was mated with a plasmid-free derivative of Pseudomonas putida NCIB 9869, strain RA713, which cannot grow on 2,5-xylenol. Some RA713 transconjugants, initially selected on 2,5-xylenol, were found to carry RP4 plasmids that had acquired additional fragments (designated XIn) which ranged in size from 2 kb to approximately 26 kb. Instability of DNA inserts in RP4::XIn hybrid plasmids was observed. The smallest insert present in a stable RP4::XIn6 hybrid plasmid, termed XIn6, yielded multiple bands when it was used as a probe with digested P25X chromosomal DNA. Sequence analysis of $X \ln 6$ led to the discovery of an open reading frame with homology to the maturases of group II introns. The XIn6 insert also exhibited several features characteristic of a group II intron. These included the presence of the consensus sequence GUGYG at the $5^{\prime}$ end and RAY at the $3^{\prime}$ end of the intron. RNA secondary structure modelling of XIn6 also revealed the presence of perfectly conserved domains V and VI. Differences were detected in the XIn6 hybridization profiles of several P25X catabolic mutants that have lost the ability to grow on 2,5-xylenol. In these mutants the loss of 2,5-xylenol degradative ability could be due to genome rearrangements mediated by sequences related to the XIn6 group II intron. This is the first reported group II intron isolated from Pseudomonas spp. and the first time that the mobility of a bacterial group II intron has been demonstrated.
\end{abstract}

Keywords: group II introns, Pseudomonas alcaligenes, 2,5-xylenol degradation

\section{INTRODUCTION}

Group II introns are mainly found in the genomes of eukaryotic organelles in fungi and plants. Group II introns are of particular interest not only as ribozymes which catalyse their own splicing, but also as mobile genetic elements (reviewed by Lambowitz \& Belfort, 1993; Michel \& Ferat, 1995). All group II introns have a conserved secondary structure which consists of six double helical domains radiating from a central wheel. This conserved structure catalyses splicing via formation

†Present address: Trinity College, Oxford OX1 3BH, UK. Abbreviations: EBS, exon-binding site; IBS, intron-binding site. The GenBank accession number for the nucleotide sequence reported in this paper is U77945. of a lariat intermediate which closely resembles the intermediate formed during the splicing of nuclear premessenger introns. The core structure of group II introns contains very few conserved nucleotides and only the first few bases of the intron and some of those constituting the small domain $\mathrm{V}$ could be considered as characteristic of group II (Michel \& Ferat, 1995). Using two degenerate primers which match these conserved regions to amplify DNA extracts by PCR, Ferat and his colleagues were able to detect group II introns in both cyanobacteria (Calothrix, Anabaena, Nostoc) and proteobacteria (Azotobacter, Escherichia) (Ferat \& Michel, 1993; Ferat et al., 1994), that is, for the first time in prokaryotes. Interestingly, all four introns identified in $E$. coli interrupt either proven or putative mobile elements. One of the four $E$. coli introns was independently identified using consensus sequences matching 
Table 1. Bacterial strains and plasmids used in this study

\begin{tabular}{|c|c|c|}
\hline Strain or plasmid & Relevant properties* & Reference/source \\
\hline \multicolumn{3}{|l|}{ Pseudomonas } \\
\hline P. alcaligenes NCIB 9867 (P25X) & Wild-type; $2,5-X \ln ^{+}$ & Hopper \& Chapman (1971) \\
\hline$P$. alcaligenes $\mathrm{P} 25 \mathrm{X} 11$ & EMS-treated derivative of $\mathrm{P} 25 \mathrm{X} ; 2,5-\mathrm{Xln}^{-}$ & Poh \& Bayly (1988) \\
\hline$P$. alcaligenes $\mathrm{S} 16$ & Spontaneous derivative of $\mathrm{P} 25 \mathrm{X} ; 2,5-\mathrm{Xln}^{-}$ & Poh \& Bayly (1980) \\
\hline P. alcaligenes $\mathrm{MC} 7$ & Mitomycin-C-treated derivative of $\mathrm{P} 25 \mathrm{X} ; 2,5-\mathrm{Xln}^{-}$ & Poh \& Bayly (1980) \\
\hline P. putida RA713 & $\begin{array}{l}\text { Plasmid-free derivative of } P . \text { putida NCIB } 9869 \text { (P35X); } \\
\text { 2,5-Xln- } 3,5-\mathrm{Xln}^{-} ; \mathrm{Sm}^{\mathrm{R}}\end{array}$ & Jain et al. (1984) \\
\hline \multicolumn{3}{|l|}{ Escherichia coli } \\
\hline $\mathrm{J} 53$ & $\mathrm{~F}^{-}$thi thr leu; host for plasmid RP4 & Miller (1972) \\
\hline JM109 & $\begin{array}{l}\mathrm{F}^{\prime} \text { traD36 proAB lacl }{ }^{9} \Delta(\text { lacZ) M15 recA1 endA1 gyrA96 } \\
\text { hsdR17 }\left(\mathrm{r}_{\mathrm{k}}^{-} \mathrm{m}_{\mathrm{k}}^{+}\right) \text {thi supE44 relA1 } \Delta(\text { lac-proAB); host for } \\
\text { pUC129 and its derivatives }\end{array}$ & Yanisch-Perron et al. (1985) \\
\hline \multicolumn{3}{|l|}{ Plasmids } \\
\hline pUC129 & $3.2 \mathrm{~kb} \mathrm{Ap}^{\mathrm{R}}$ cloning vector & Keen et al. (1988) \\
\hline RP4 & $60 \mathrm{~kb}$ IncP broad-host-range plasmid; $A \mathrm{p}^{\mathrm{R}} \mathrm{Km}^{\mathrm{R}} \mathrm{Tc}^{\mathrm{R}}$ & Datta et al. (1971) \\
\hline $\mathrm{RP} 4:: \mathrm{X} \ln 6$ & $\begin{array}{l}2.0 \mathrm{~kb} \text { of P25X DNA inserted into RP4 near Ap }{ }^{\mathrm{R}} \text { gene; } \\
\text { smallest of RP4::Xln hybrid plasmids; does not confer } \\
\text { growth on } 2,5 \text {-xylenol upon RA713 }\end{array}$ & This study \\
\hline pCC129X6 & $\begin{array}{l}2.6 \mathrm{~kb} S m a \mathrm{I} \text { fragment containing part of Xln6 fragment } \\
\text { and flanking RP4 sequences cloned into pUC129 }\end{array}$ & This study \\
\hline
\end{tabular}

"Phenotype designations: $2,5-\mathrm{X} \ln ^{+}$, ability to grow on 2,5 -xylenol; $2,5-\mathrm{Xln}^{-}$, no growth on 2,5 -xylenol; 3,5-Xln", no growth on 3,5xylenol.

domain V to search the databases (Knoop \& Brennicke, 1994; Knoop et al., 1994). The database search also yielded putative group II intron sequences in plasmidborne insertion sequence elements in Agrobacterium tumefaciens and rhizobia as well as a strain of Yersinia pseudotuberculosis (Knoop \& Brennicke, 1994). Recently, group II introns were found in a region involved in the conjugative transfer of a Lactococcus lactis conjugative plasmid (Mills et al., 1996) as well as a chromosomally located sex factor which controls conjugation in L. lactis (Shearman et al., 1996). A transposon isolated from Clostridium difficile was recently shown to harbour a group II intron (Mullany et al., 1996). Group II introns thus appear to have a widespread distribution in the prokaryotic world although the true extent of their occurrence in prokaryotes has yet to be determined.

Pseudomonas alcaligenes NCIB 9867 (strain P25X) was isolated from river mud in Hull, UK; it is able to degrade 2,5-xylenol, 3,5-xylenol and $m$-cresol via the gentisate pathway (Hopper \& Chapman, 1971). Spontaneous loss of the ability of P25X to degrade 2,5-xylenol was reported to occur at a frequency of $3-5 \%$ and this rate of loss could be increased to $40-50 \%$ in the presence of mitomycin $\mathrm{C}$ or by growth at $42^{\circ} \mathrm{C}$ (Poh \& Bayly, 1980). This high frequency of loss could be explained if the genes for 2,5-xylenol degradation were carried on a plasmid or on a mobile genetic element. Strain P25X was found to harbour an approximately $33 \mathrm{~kb}$ plasmid, pRA2; however, all P25X mutants which had lost the ability to grow on 2,5-xylenol were found to carry an identical plasmid (C. L. Poh, unpublished results). To investigate the presence of mobile genetic elements in $\mathrm{P} 25 \mathrm{X}$, the plasmid RP4 was used as a target DNA in conjugative transposition experiments. Here, we report the in vivo construction of several RP4::Xln hybrid plasmids and the discovery that the smallest of these hybrid plasmids, RP4:: Xln6, harbours a group II intron, the first to be reported in Pseudomonas. Although several eukaryotic group II introns are capable of homing (i.e. converting intron-less alleles to the intronplus state) as well as transposing to new insertion sites (Mueller et al., 1993; Sellem et al., 1993; Moran et al., 1995), the mobility of bacterial group II introns has not yet been demonstrated before. In this report, we also explore the possibility that the genes for 2,5-xylenol degradation are localized in the vicinity of group II introns.

\section{METHODS}

Bacterial strains and plasmids. The Pseudomonas and Escherichia coli strains, as well as the plasmids used and constructed during the course of this study, are described in Table 1.

Media and culture conditions. LB agar and LB broth were prepared according to Miller (1972). Media containing aromatic compounds as sole carbon sources were made by adding the aromatic compound to the basal minimal medium (Hegeman, 1966) to a final concentration of $2.5 \mathrm{mM}$. $P$. alcaligenes $\mathrm{P} 25 \mathrm{X}$ and $P$. putida RA713 transconjugants harbouring RP4::Xln hybrid plasmids were maintained on minimal agar plates containing 2,5-xylenol as the sole carbon 
source. P. putida RA713 harbouring RP4::Xln6 and E. coli hosts containing RP4 and its derivatives were maintained on LB agar containing kanamycin $\left(\mathrm{Km}, 50 \mu \mathrm{g} \mathrm{ml}^{-1}\right)$ and tetracycline $\left(\mathrm{Tc}, 30 \mu \mathrm{g} \mathrm{ml}^{-1}\right.$ ) while $E$. coli hosts containing derivatives of pUC129 were maintained on LB agar containing ampicillin (Ap, $100 \mu \mathrm{g} \mathrm{ml}^{-1}$ ). Streptomycin (Sm) was used at a final concentration of $500 \mu \mathrm{g} \mathrm{ml}^{-1}$. All Pseudomonas spp. were grown at $32{ }^{\circ} \mathrm{C}$; E. coli was grown at $37^{\circ} \mathrm{C}$.

Bacterial conjugation by membrane filter mating. Plasmid RP4 and its hybrid derivatives were introduced into Pseudomonas by membrane filter mating as described by Bagdasarian et al. (1981). Equal volumes of donor and recipient cells were filtered through a $25 \mathrm{~mm}$ diameter membrane filter with pore size of $0.45 \mu \mathrm{m}$. The filter was placed on an LB agar plate and incubated for $2 \mathrm{~d}$ at $32^{\circ} \mathrm{C}$. The filter was then washed with sterile minimal medium and the cells plated out onto selection plates.

DNA manipulations. Plasmid DNA was prepared by alkaline lysis (Birnboim \& Doly, 1979). For large-scale preparations, plasmid DNA was further purified through a caesium chloride/ethidium bromide density gradient as described by Sambrook et al. (1989). Genomic DNA was prepared according to the method described by Ausubel et al. (1987).

Recombinant plasmids were constructed by standard protocols (Sambrook et al., 1989). Labelled probes for Southern hybridization analysis were made with horseradish peroxidase labelling reactions using the enhanced chemoluminescence (ECL) direct nucleic acid labelling system from Amersham.

DNA sequencing and computer analysis. Nested deletions of the pUC129 clone, pCC129X6, were generated using the double-stranded nested deletion kit (Pharmacia). Nucleotide sequencing was carried out using the ABI PRISM Dye Terminator Cycle Sequencing Ready Reaction kit and the Applied Biosystems DNA Sequenator ABI 373 (Applied Biosystems/Perkin Elmer) on double-stranded templates. Sequencing of deletion fragments in pUC129 were carried out using either the pUC18 forward (5'-TGTAAACGACGGCCAGT-3') or reverse (5'-CAGGAAACAGCTATGAC-3') primers. To complete the sequence of $\mathrm{X} \ln 6$, a series of 18 -mer primers were used to 'walk' along RP4::Xln6 in both the forward and reverse orientations.

The nucleotide sequences and deduced amino acid sequences were analysed using DNASIS and PROSIS (Hitachi Software Engineering) respectively. The BLAST program at the National Centre for Biotechnology Information (NCBI) was used to search for DNA and amino acid homologies in the databases.

\section{RESULTS}

\section{In vivo construction of RP4::XIn hybrid plasmids}

The broad-host-range plasmid RP4 was introduced into $P$. alcaligenes $\mathrm{P} 25 \mathrm{X}$ by conjugation with $E$. coli $\mathrm{J} 53$ carrying RP4. Transconjugants were selected on 2,5xylenol plates containing $\mathrm{Km}$. Analysis of a few transconjugants which grew on 2,5-xylenol showed the presence of enlarged RP4 plasmids. When the additional fragments from the RP4 hybrid plasmids were used in Southern hybridization with P25X genomic DNA, multiple hybridizing bands were observed. No hybridization was observed between RP4 and the P25X genomic DNA. $P$. alcaligenes strains carrying these RP4:: Xln hybrid plasmids were then used as donors in

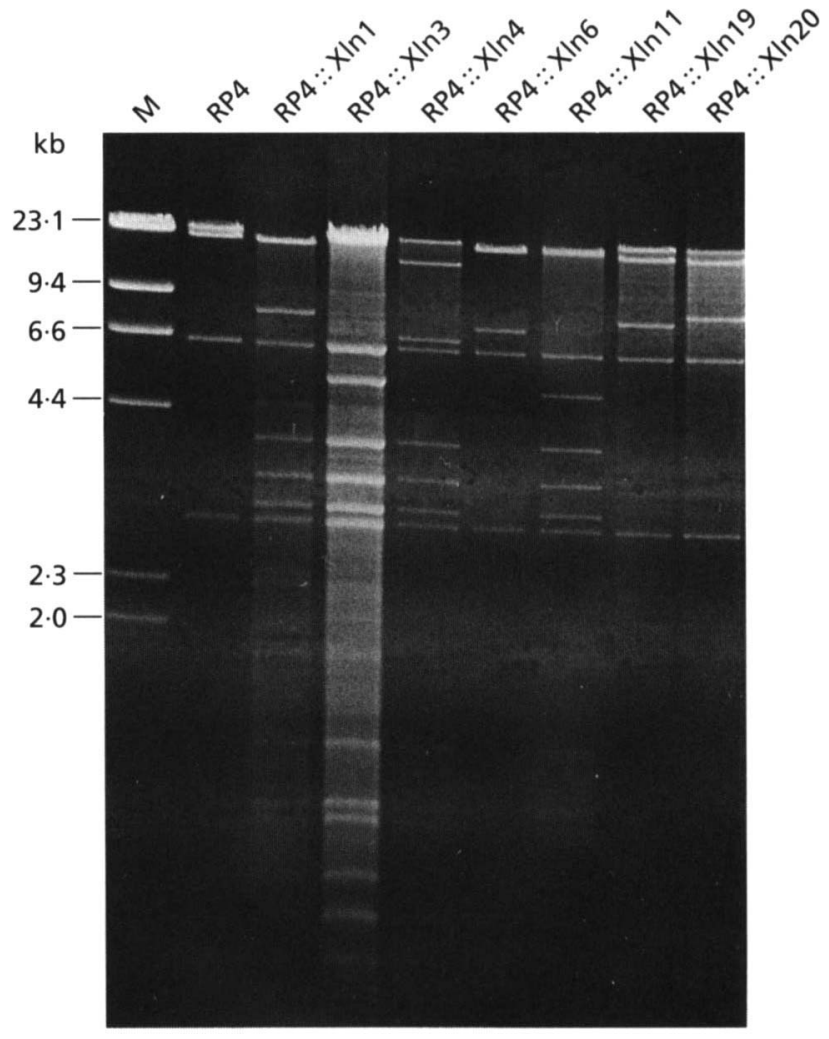

Fig. 1. Agarose gel electrophoresis of plasmid RP4 and several RP4::XIn hybrid plasmids digested with Pstl. $\lambda$ DNA restricted with HindIII served as the size marker (lane $M$ ).

further conjugation experiments with $P$. putida RA713, a plasmid-free, $\mathrm{Sm}^{\mathrm{R}}$-derivative of $P$. putida $\mathrm{NCIB} 9869$ (P35X) which did not express the genes for the gentisate (2,5-dihydroxybenzoate) pathway (Jain et al., 1984). RA713 transconjugants that could grow on 2,5-xylenol plates supplemented with $\mathrm{Km}$ and $\mathrm{Sm}$ were selected. Transconjugants appeared at a low frequency of approximately $1 \times 10^{-8}$. The ability to grow on 2,5 xylenol was found to be unstable in some of the transconjugants (four of the nine transconjugants obtained lost the ability to grow on 2,5-xylenol upon subsequent passages) but the loss of this ability did not lead to a loss of any of the antibiotic resistance markers encoded by RP4 (i.e. Ap, Km and Tc). Plasmids isolated from the RA713 transconjugants showed the presence of additional fragments ranging from approximately $2 \mathrm{~kb}$ in RP4::Xln6 to about $26 \mathrm{~kb}$ in RP4::Xln1 (Fig. 1).

\section{Subcloning and sequencing of the insertion fragment in RP4:: XIn6}

Restriction analysis of RP4::X $\ln 6$ showed that a $2 \mathrm{~kb}$ insertion, designated as Xln6, was located around coordinate 0 of the RP4 plasmid (Lanka et al., 1983) close to the $A p^{R}$ gene. Southern hybridization analysis revealed that the sequences related to the $X \ln 6$ fragment were repeated numerous times in the P25X genome (Fig. 


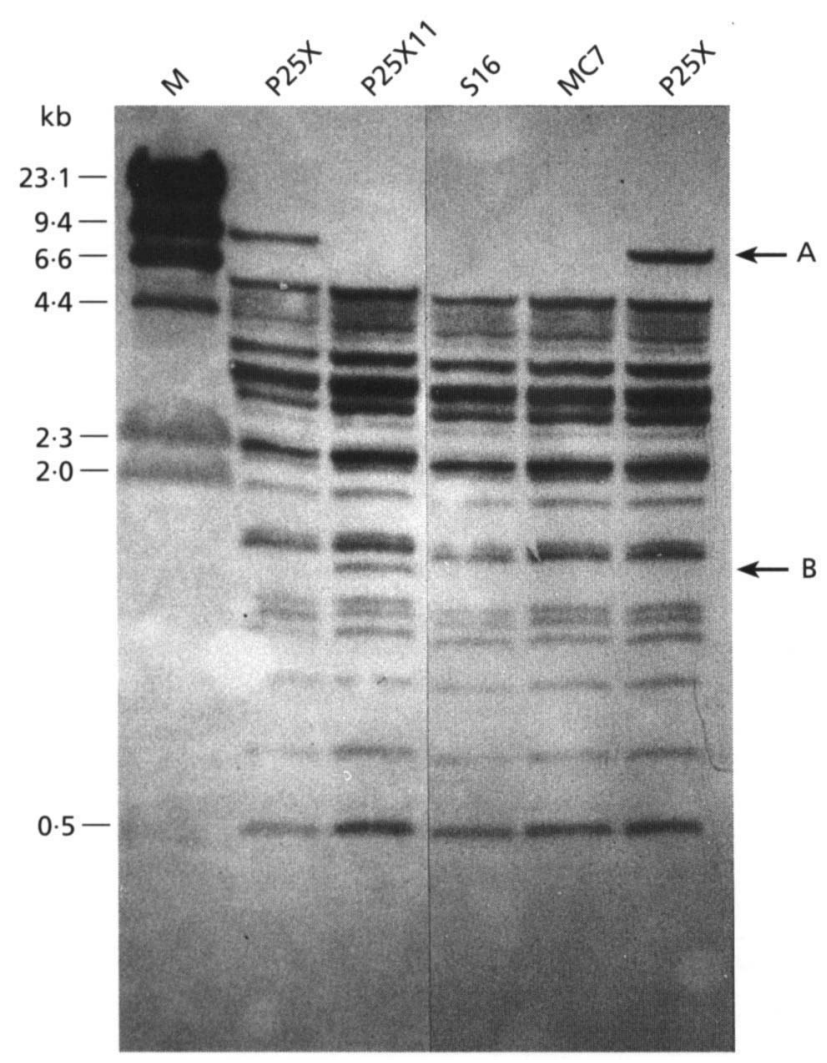

Fig. 2. Hybridization profiles of strain $P 25 X$ wild-type, and $P 25 X$ catabolic mutants P25X11, S16 and MC7, which have lost the ability to degrade 2,5-xylenol (Poh \& Bayly, 1980; 1988), using a 484 bp internal fragment $X \ln 6$ (nucleotides 796-1280), obtained from a nested deletion clone of pCC129X6, as a probe against genomic digests. Note the absence of an approximately $9.4 \mathrm{~kb}$ hybridization band in all the catabolic mutants (marked A) and the presence of an additional $1.5 \mathrm{~kb}$ hybridization band in P25X11 (marked B). Hybridization conditions were as follows. The blot was placed in a hybridization buffer containing $0.5 \mathrm{M}$ $\mathrm{NaCl}$ and $10 \mathrm{ng}$ probe $\mathrm{ml}^{-1}$ at $42^{\circ} \mathrm{C}$ overnight. A high-stringency wash was used by making the primary wash buffer (containing $6 \mathrm{M}$ urea and $0.4 \%$ SDS) in $0.1 \times$ SSC from a $20 \times$ SSC stock $(0.3 \mathrm{M}$ trisodium citrate, $3 \mathrm{M} \mathrm{NaCl} ; \mathrm{pH} 7 \cdot 0$ ). $\lambda$ DNA restricted with HindIII served as the size marker (lane $M$ ).

2). Attempts to subclone the entire $X \ln 6$ fragment into pUC129 failed. However, we managed to subclone a $2.6 \mathrm{~kb} \mathrm{SmaI} \mathrm{fragment} \mathrm{which} \mathrm{comprised} 1.3 \mathrm{~kb}$ of the $\mathrm{X} \ln 6$ fragment as well as $1.3 \mathrm{~kb}$ of surrounding RP4 sequences into pUC129. The sequence data generated from this clone allowed us to synthesize primers to further sequence the remainder of the $\mathrm{X} \ln 6$ fragment using RP4:: $\mathrm{X} \ln 6$ as the template.

\section{Sequence analysis of XIn6 and its identification as a group II intron}

The entrapment of $\mathrm{X} \ln 6$ in $\mathrm{RP} 4$ was suggestive of mobility, but a nucleotide sequence database search with BLAST (Altschul et al., 1990) showed that Xln6 did not have any significant homology to known mobile genetic elements. Identification of flanking RP4 sequences indicated that the $\mathrm{X} \ln 6$ insert spanned $1919 \mathrm{bp}$. Nucleotide sequence analysis of $\mathrm{X} \ln 6$ revealed an open reading frame (ORF) which spanned nucleotides 429-1900 (Fig. 3) and could potentially encode a $56175 \mathrm{Da}$ protein of 490 amino acid residues.

The ORF-encoded protein of Xln6, designated OrfX6, was found to have extensive similarity to the ORFencoded maturases of eukaryotic group II introns (Lambowitz \& Belfort, 1993; Michel \& Ferat, 1995) and recently identified bacterial group II introns (Ferat \& Michel, 1993; Ferat et al., 1994; Mills et al., 1996; Mullany et al., 1996; Shearman et al., 1996). About a quarter of the known group II introns potentially encode proteins called maturases (Michel \& Ferat, 1995) and most of them include a domain with obvious homology to the polymerase domain of reverse transcriptases (Michel \& Lang, 1985). The Xln6-encoded maturase, OrfX6, contained all seven polymerase-like domains conserved among retroelement reverse transcriptases (RT1 to RT7) (Fig. 4) (Xiong \& Eickbush, 1990). A domain $\mathrm{Z}$ was detected at the $\mathrm{N}$-terminal end of the $\mathrm{X} \ln 6$ maturase. This domain is normally found upstream of the reverse transcriptase domain in retroid elements devoid of long-terminal repeats (LTRs) (Xiong \& Eickbush, 1990). A domain X, which had been suggested to be involved in binding of the intron RNA during reverse transcription and splicing (Mohr et al., 1993), was found downstream of the $X \ln 6$ reverse transcriptase domains.

The Xln6 intron boundaries showed the strongly conserved consensus sequence GUGYG at the $5^{\prime}$ end and RAY at the 3' end of the intron (Michel et al., 1989). The $3^{\prime}$ end of the $X \ln 6$ intron could also be folded into perfect domain V and VI RNA secondary structures characteristic of group II introns (Fig. 5a) (Michel et al., 1989). Domain VI contained a bulging adenine residue seven bases from the $3^{\prime}$ splice site which has been demonstrated to constitute a $2^{\prime}$ to $5^{\prime}$ lariat branch point in several group II introns (Michel et al., 1989; Michel \& Ferat, 1995). Relevant domain V features of a bulging CG dinucleotide and a purine-rich terminal loop of four nucleotides (Michel et al., 1989; Knoop \& Brennicke, 1994) were also observed in the Xln6 group II intron.

A combination of comparative analysis (Michel et al., 1989) and computer modelling allowed us to identify an exon-binding site loop (EBS1) (5'-ACAAATC- $\left.3^{\prime}\right)$ in domain I of the Xln6 group II intron. A search of the RP4 sequences upstream of the intron revealed an intron-binding-site-like (IBS1-like) sequence motif $\left(5^{\prime}\right.$ TGTTTTG-3') which could potentially base-pair with the EBS1 loop (albeit with one mismatch).

\section{Relationship of the XIn6 group II intron with 2,5-xylenol degradative genes}

When the Xln6 group II intron was used as a probe against genomic digests of several P25X catabolic mutants which have lost their ability to degrade 2,5xylenol, differences were observed in the hybridization 


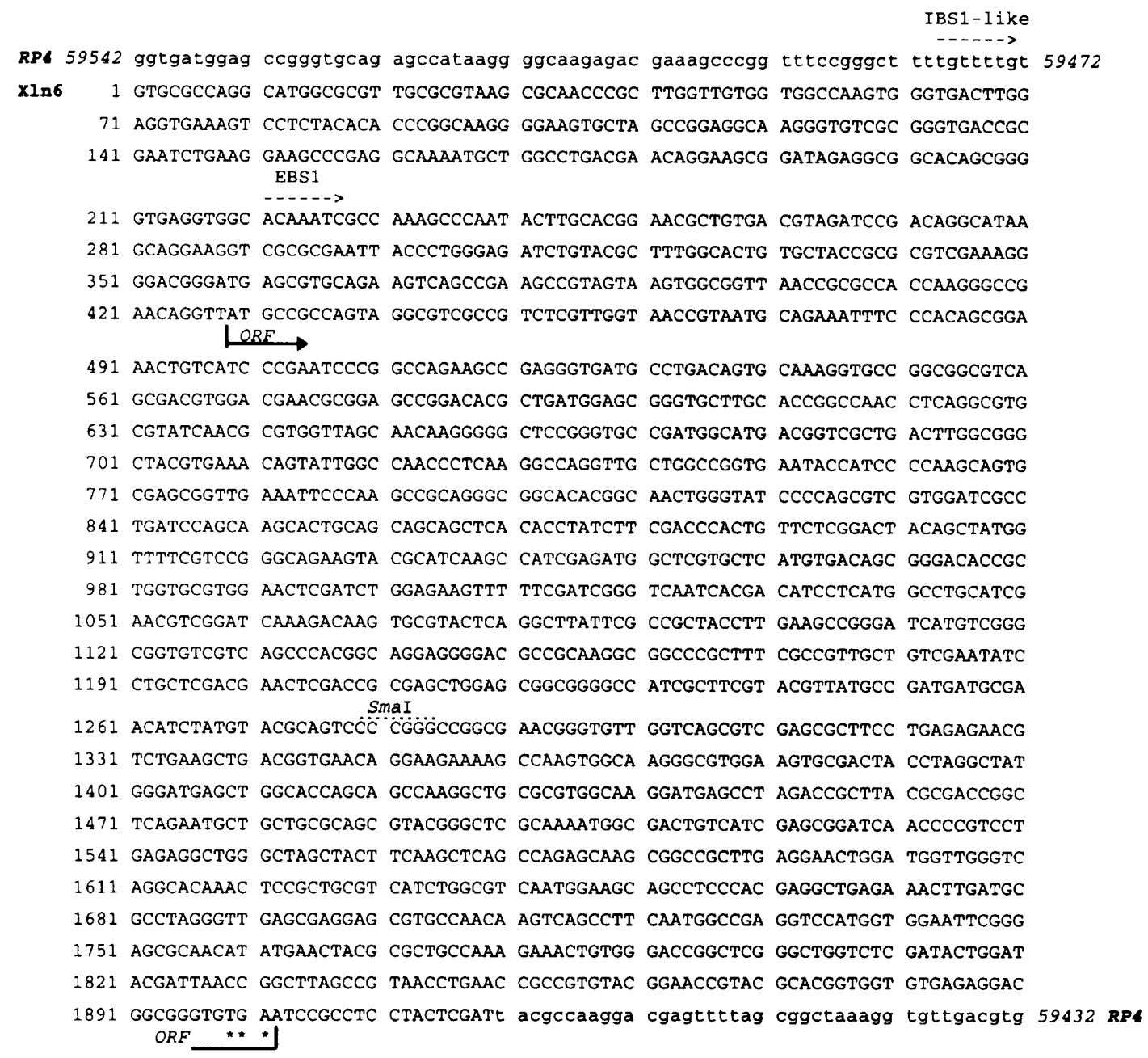

Fig. 3. Nucleotide sequence of the XIn6 group II intron and flanking RP4 sequences (shown in lower-case letters). The RP4 sequence was numbered (in italics) according to Pansegrau et al. (1994). The ORF which encodes the maturaserelated protein is enclosed in brackets. The stop codon is marked by asterisks. The Smal site used for cloning is shown (the XIn6 fragment cloned in pCC129X6 was from nucleotides 1 to 1281). The nucleotide sequences which form the EBS1 loop in the XIn6 intron and the RP4 IBS1-like sequences upstream of the intron are overlined with dashed arrows.

profiles when compared with the wild-type P25X (Fig. 2). An approximately $9.4 \mathrm{~kb}$ hybridization band (A) was notably absent in all the catabolic mutants screened while in one mutant, P25X11, an additional $1.5 \mathrm{~kb}$ hybridization band was observed. The results strongly suggest that genomic rearrangements mediated by the Xln6 group II intron could have led to the loss of genes involved in the degradation of 2,5-xylenol.

In searching for nucleotide sequence homology with the databases, we found that the region of Xln6 which could fold into the domain VI RNA secondary structure (nucleotides 1871-1919) showed sequence identity, with only three point differences, with a noncoding region immediately downstream of the $p$-cresol hydroxylase gene ( $p c h F$ ) from both Pseudomonas putida NCIB 9869 (strain P35X) and P. putida NCIB 9866 (strain P24X) (Kim et al., 1994) (Fig. 5b). Two of these three differences in the flanking $p c h F$ sequence consist of compensatory base substitutions which would still allow the sequence to fold into a characteristic domain VI secondary structure.

\section{DISCUSSION}

Bacterial group II introns were first detected in cyanobacteria and proteobacteria, which include the presumptive ancestors of chloroplasts and mitochondria, respectively. However, since then, group II introns have been discovered in bacteria as diverse as E. coli (Ferat et al., 1994), agrobacteria and rhizobia (Knoop \& Brennicke, 1994), lactococci (Mills et al., 1996; Shearman et al., 1996) and Clostridium difficile (Mullany et al., 1996). The GC content of all bacterial group II introns sequenced so far, including XIn6, reflects the GC content of their hosts, suggesting that these introns are not a recent introduction but, rather, are long-term residents of their bacterial hosts. Our finding of a group II intron in P. alcaligenes further extends the known distribution of these elements in 


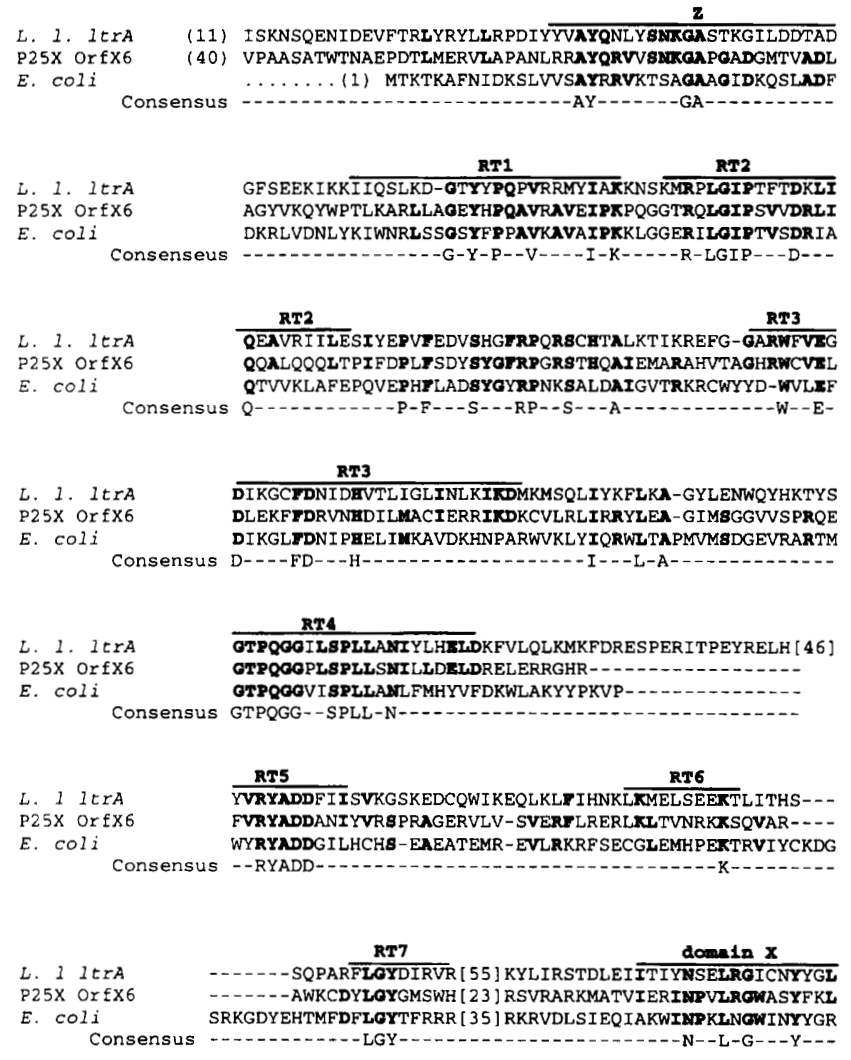

Fig. 4. Protein alignment of the putative ORF1-encoded protein of XIn6, OrfX6, with prokaryotic group II intron-encoded ORFs from E. coli (Ferat et al., 1994) and Lactococcus lactis (L. I. ItrA) (Mills et al., 1996). Identical amino acid sequences are in bold letters. Domains conserved among intron-encoded ORFs are denoted by the lines above the alignment. RT1 through RT7 depict reverse transcriptase (RT)-like domains. $Z$ refers to a domain of undetermined function in non-long-terminal-repeat retroelements (Xiong \& Eickbush, 1990); the maturase-specific domain is designated $X$ (Mohr et al., 1993).

diverse bacterial groups. The possibility for intron dissemination via horizontal transfer exists in bacteria, as all the bacterial group II introns found so far are associated with insertion sequence elements (Ferat $e t$ al., 1994; Knoop \& Brennicke, 1994), a conjugative transposon (Mullany et al., 1996), a lactococcal conjugative plasmid (Mills et al., 1996) and a lactococcal chromosomal sex factor (Shearman et al., 1996).

We believe that group II introns are indeed widespread in bacteria, but the search strategies employed thus far have not been exhaustive (Ferat \& Michel, 1993; Michel \& Ferat, 1995). Searching is difficult as the core structure of group II introns contains very few conserved nucleotides. A good example of the diversity of group II intron structures could be found in the chloroplast genome of Euglena gracilis (reviewed by Copertino \& Hallick, 1993), where bona fide, although somewhat defective, group II introns coexist with numerous smaller introns that share the same lariat-forming mode of excision but lack any recognizable cognate of even domain $\mathrm{V}$.
The mechanism for eukaryotic group II intron mobility is only begining to be elucidated. It was suggested that the yeast mitochondrial group II intron, aI2, acted as a site-specific retroposon (Moran et al., 1995) and its homing was dependent on both the reverse transcriptase domains as well as an endonuclease activity of the zinc finger domain (Zimmerly et al., 1995). The yeast al1 intron was recently shown to encode an analogous endonuclease specific for a different target site to the aI2 intron and more than half of aI1 molecules were reported to undergo complete reverse splicing in vitro, integrating linear intron RNA directly into DNA (Yang et al., 1996).

Although bacterial group II intron mobility has never been proven, few of the introns characterized revealed flanking exons potentially involved in DNA mobility (Knoop \& Brennicke, 1994; Ferat et al., 1994). The entrapment of the $P$. alcaligenes $\mathrm{P} 25 \mathrm{X}$ Xln6 group II intron in RP4 demonstrated, for the first time, the mobility of a bacterial group II intron. It is interesting to note that an IBS1-like sequence could be detected in the target RP4 plasmid immediately upstream of the inserted Xln6 intron. All cases of spontaneous group II transposition investigated so far have turned out to occur immediately downstream of an IBS1-like sequence (Mueller et al., 1993; Michel \& Ferat, 1995).

The criterion for selection of the RP4::Xln hybrid plasmids was growth of the recipient $P$. putida RA713 on 2,5-xylenol. The newly acquired 2,5-xylenol degradative ability in RA713 carrying RP4::Xln6 was unstable. Analysis of RP4::Xln6 hybrid plasmids from RA713 hosts that failed to utilize 2,5-xylenol showed that there was a reduction in size of the inserted fragment. Preliminary analysis of RP4 : : Xln 6 had shown that the insert was $12.6 \mathrm{~kb}$ in size (Tham, 1993); however, upon subsequent passages, the plasmid was observed to have lost approximately $10.6 \mathrm{~kb}$ of DNA coinciding with the loss of the ability of the plasmid to confer growth on 2,5-xylenol upon the host. The results indicated that in RA713 harbouring the stable form of RP4::Xln6, a rearrangement had taken place resulting in the loss of DNA which had enabled the host RA713 to grow initially on 2,5-xylenol. Two possibilities could be offered regarding the mobility of the Xln6 intron. One, the Xln6 intron was associated with a mobile element which had transposed onto RP4 and later underwent further rearrangements, leaving the Xln6 intron on RP4. This is possible as some of the bacterial group II introns discovered have been associated with mobile elements (Ferat et al., 1994; Knoop \& Brennicke, 1994). Alternatively, the Xln6 intron itself could have pulled its flanking exons during its transposition into RP4 but these flanking regions were rather unstable and were concomitantly lost from the hybrid plasmid. In eukaryotic group II introns that have been shown to be mobile, transposition was reported to occur at a much lower frequency compared to homing (i.e. insertion into an intronless allele) (Michel \& Ferat, 1995; Moran et al., 1995). Intron homing was found to be accompanied by preferential transmission of markers flanking the intron (Michel \& Ferat, 1995). However, for the yeast 
(a)

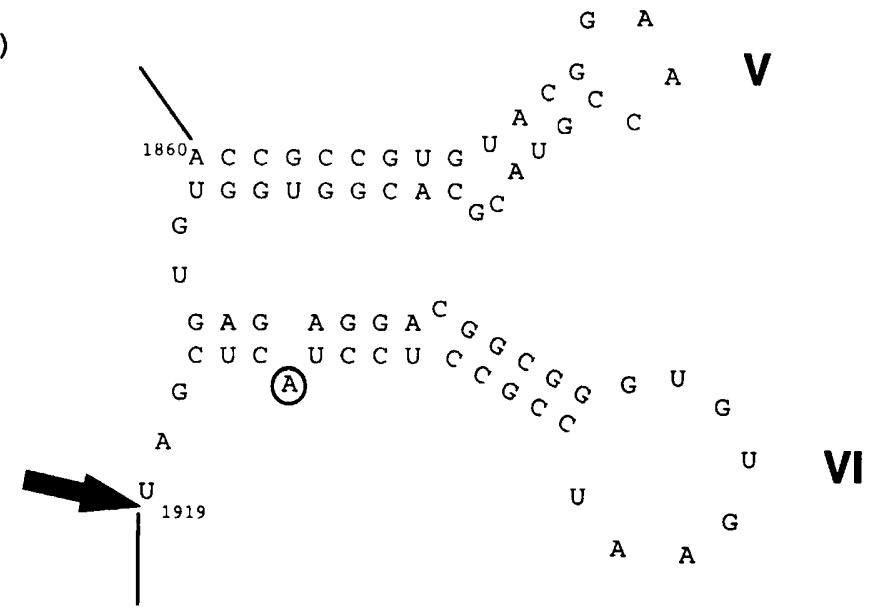

(b) ter $G \quad T \quad A \quad L<----p c h F$ ACTCTCCTGC-GCCGACACTTCGGCGGAGGATGAGCTAAATTGGCCACCGATTGG-5' TGAGAGGACG-CGGCTGTGAAGCCGCCTCCTACTCGATTTAACCGGTGGCTAACC-3 $-->-->--->\quad<----<---<--$ TGAGAGGACGGCGGGTGTGAATCCGCCTCCTACTCGAT (end of RP4 insert) $-->--->--->\quad<----<--<<-$ domain VI
Fig. 5. (a) RNA secondary structure of domains $\mathrm{V}$ and $\mathrm{VI}$ of the XIn6 group II intron. The boundary of the intron and plasmid RP4 is indicated by an arrow. The bulging adenine residue involved in lariat formation is circled. Numbers refer to the nucleotide sequence of $X \ln 6$ as shown in Fig. 3. (b) Nucleotide sequence alignment of the $X \ln 6$ intron domain VI with the noncoding region downstream of the pchF gene of Pseudomonas putida NCIB 9869 and $P$. putida NCIB 9866 (Kim et al., 1994) (nucleotides 1741-1777). Dashed arrows show nucleotide sequences which could base-pair to form the domain VI secondary structure. Note that the intron-like sequence is in an orientation opposite to that of the pchF gene and ends precisely at the pchF termination codon (marked 'ter'). The two nucleotide sequence differences in the $p c h F$ flanking sequence are highlighted in bold. group II introns al1 and al2, co-conversion associated with the transfer of the introns was reported to be limited to fewer than $100 \mathrm{bp}$ in exon 1 and fewer than $23 \mathrm{bp}$ in exon 3 (Moran et al., 1995). Thus for a transposing $\mathrm{X} \ln 6$ to bring along flanking exons which confer growth on 2,5-xylenol would mean co-conversion of a fairly large fragment of DNA. This possibility, although unprecedented, should not be totally dismissed as no in-depth study of the mobility of bacterial group II introns has been carried out.

Even though RP4::XIn6 was unable to confer growth on 2,5-xylenol upon RA713, some of the other RP4:: XIn hybrid plasmids did. Efforts are under way to further characterize these hybrid plasmids and to investigate the relationship of group II introns and 2,5-xylenol degradative genes. The $9.4 \mathrm{~kb}$ P25X DNA fragment which was found to be missing in all the 2,5-xylenolnegative catabolic mutants (Fig. 2) is also being cloned and characterized. Results of Southern hybridization clearly showed that in these P25X catabolic mutants, genome rearrangements mediated by sequences related to the Xln6 group II intron had taken place. DNA sequences bounded by two Xln6 group II introns could have been deleted as a result of recombination between the introns. These DNA sequences could encode 2,5xylenol degradative genes. The presence of an additional $1.5 \mathrm{~kb}$ fragment in the DNA hybridization profile of mutant P25X11 (marked B in Fig. 2) when Xln6 was used as a hybridizing probe suggested the insertion of part of the group II intron into either the structural or regulatory genes of the gentisate pathway. Disruption of these genes could lead to the non-functioning of the gentisate pathway in the mutant.

A noncoding region immediately downstream of the $p c h F$ gene that exhibited high homology with domain VI of the Xln6 group II intron and which could potentially fold into a characteristic domain VI secondary structure strongly suggests that a group II intron is associated with the $p c h F$ gene, which is involved in the degradation of $p$-cresol via the ortho pathway. This intron-like sequence, which is in an opposite orientation to the $p c h F$ gene and ends precisely at the $p c h F$ termination codon, has an unprecedented arrangement for introns and flanking sequences. The extent of the involvement of group II introns in biodegradative pathways clearly needs further investigation and it remains to be seen if group II introns play an important role in the evolution of catabolic functions, much like other mobile genetic elements.

\section{ACKNOWLEDGEMENTS}

This work was supported by National University of Singapore Academic Research Grant no. RP-95-0383 to C. L. Poh. J. M. Tham was a Singapore National Science and Technology Board Postdoctoral fellow. C. C. Yeo was a recipient of the National University of Singapore postgraduate scholarship.

\section{REFERENCES}

Altschul, S. F., Gish, W., Miller, W., Myers, E. W. \& Lipman, D. J. (1990). Basic local alignment search tool. J Mol Biol 215, 403-410.

Ausubel, F. M., Brent, R., Kingston, R. E., Moore, D. D., Smith, J. A., Seidman, J. G. \& Struhl, K. (1987). Current Protocols in Molecular Biology. New York: John Wiley.

Bagdasarian, M., Lunz, R., Ruckert, B., Franklin, F. C. H., Bagdasarian, M. M., Frey, J. \& Timmis, K. N. (1981). Specific purpose cloning vectors. II. Broad-host-range, high-copy-number, RSF1010-derived vectors, and a host-vector system for gene cloning in Pseudomonas. Gene 16, 237-247. 
Birnboim, H. C. \& Doly, J. (1979). A rapid alkaline extraction procedure for screening recombinant plasmid DNA. Nucleic Acids Res 7, 1513-1523.

Copertino, D. W. \& Hallick, R. B. (1993). Group II and group III introns of twintrons: potential relationships with nuclear premRNA introns. Trends Biochem Sci 18, 467-471.

Datta, N., Hedges, R. W., Shaw, E. J., Sykes, R. B. \& Richmond, M. H. (1971). Properties of an R-factor from Pseudomonas aeruginosa. J Bacteriol 108, 1244-1249.

Ferat, J.-L. \& Michel, F. (1993). Group II self-splicing introns in bacteria. Nature 364, 358-361.

Ferat, J.-L., Le Gouar, M. \& Michel, F. (1994). Multiple group II self-splicing introns in mobile DNA from Escherichia coli. $C R$ Acad Sci 317, 141-148.

Hegeman, G. D. (1966). Synthesis of enzymes of the mandelate pathway by Pseudomonas putida. 1. Synthesis of enzymes by the wild-type. J Bacteriol 91, 1140-1154.

Hopper, D. J. \& Chapman, P. J. (1971). Gentisic acid and its 3- and 4-methyl-substituted homologues as intermediates in the bacterial degradation of $m$-cresol, 3,5-xylenol and 2,5-xylenol. Biochem J 122, 19-28.

Jain, R. K., Bayly, R. C. \& Skurray, R. A. (1984). Characterization and physical analysis of a 3,5-xylenol degradative plasmid in Pseudomonas putida. J Gen Microbiol 130, 3019-3028.

Keen, N. T., Tamaki, S., Kobayashi, D. \& Trollinger, D. (1988). Improved broad-host-range plasmids for DNA cloning in gramnegative bacteria. Gene 70, 191-197.

Kim, J., Fuler, J. H., Cecchini, G. \& McIntire, W. S. (1994). Cloning, sequencing, and expression of the structural genes for the cytochrome and flavoprotein subunits of $p$-cresol methylhydroxylase from two strains of Pseudomonas putida. J Bacteriol 174, 6349-6361.

Knoop, V. \& Brennicke, A. (1994). Evidence for a group II intron in Escherichia coli inserted into a highly conserved reading frame associated with mobile DNA sequences. Nucleic Acids Res 22, 1167-1171.

Knoop, V., Kloska, S. \& Brennicke, A. (1994). On the identification of group II introns in nucleotide sequence data. J Mol Biol 242 , 389-396.

Lambowitz, A. M. \& Belfort, M. (1993). Introns as mobile genetic elements. Annu Rev Biochem 62, 587-622.

Lanka, E., Lunz, R. \& Furste, J. P. (1983). Molecular cloning and mapping of SphI restriction fragments of plasmid RP4. Plasmid 10, 303-307.

Michel, F. \& Ferat, J.-L. (1995). Structure and activities of group II introns. Annu Rev Biochem 64, 435-461.

Michel, F. \& Lang, B. F. (1985). Mitochondrial class II introns encode proteins related to reverse transcriptases of retroviruses. Nature 316, 641-643.

Michel, F., Umesono, K. \& Ozeki, H. (1989). Comparative and functional anatomy of group II catalytic introns - a review. Gene $82,5-30$.

Miller, J. H. (1972). Experiments in Molecular Genetics. Cold Spring Harbor, NY: Cold Spring Harbor Laboratory.
Mills, D. A., McKay, L. L. \& Dunny, G. M. (1996). Splicing of a group II intron involved in the conjugative transfer of pRS01 in lactococci. J Bacteriol 178, 3531-3538.

Mohr, G., Perlman, P. S. \& Lambowitz, A. M. (1993). Evolutionary relationships among group II intron-encoded proteins and identification of a conserved domain that may be related to maturase function. Nucleic Acids Res 21, 4991-4997.

Moran, J. V., Zimmerly, S., Eskes, R., Kennell, J. C., Lambowitz, A. M., Burtow, R. A. \& Perlman, P. S. (1995). Mobile group II introns of yeast mitochondrial DNA are novel site-specific retroelements. Mol Cell Biol 15, 2828-2838.

Mueller, M. W., Allmaier, M., Eskes, R. \& Schweyen, R. J. (1993). Transposition of group II intron al1 in yeast and invasion of mitochondrial genes at new locations. Nature 366, 174-176.

Mullany, P., Pallen, M., Wilks, M., Stephen, J. R. \& Tabaqchali, S. (1996). A group II intron in a conjugative transposon from the gram-positive bacterium Clostridium difficile. Gene 174, 145-150.

Pansegrau, W., Lanka, E., Barth, P. T., Figurski, D. H., Guiney, D. G., Haas, D., Helinski, D. R., Schwab, H., Stanisich, V. A. \& Thomas, C. M. (1994). Complete nucleotide sequence of Birmingham IncP- $\alpha$ plasmids: compilation and comparative analysis. $J$ Mol Biol 239, 623-663.

Poh, C. L. \& Bayly, R. C. (1980). Evidence for isofunctional enzymes used in $m$-cresol and 2,5-xylenol degradation via the gentisate pathway. J Bacteriol 143, 59-69.

Poh, C. L. \& Bayly, R. C. (1988). Regulation of isofunctional enzymes in Pseudomonas alcaligenes mutants defective in the gentisate pathway. J Appl Bacteriol 64, 451-458.

Sambrook, J., Fritsch, E. F. \& Maniatis, T. (1989). Molecular Cloning: a Laboratory Manual, 2nd edn. Cold Spring Harbor, NY: Cold Spring Harbor Laboratory.

Sellem, C. H., Lecellier, G. \& Belcour, L. (1993). Transposition of a group II intron. Nature 366, 176-178.

Shearman, C., Godon, J.-J. \& Gasson, M. (1996). Splicing of a group II intron in a functional transfer gene of Lactococcus lactis. Mol Microbiol 21, 45-53.

Tham, J. M. (1993). Genetic analysis of Pseudomonas alcaligenes NCIB 9867. PhD thesis, National University of Singapore.

Xiong, Y. \& Eickbush, T. H. (1990). Origin and evolution of retroelements based upon their reverse transcriptase sequences. EMBO J 9, 3353-3362.

Yang, J., Zimmerly, S., Perlman, P. S. \& Lambowitz, A. M. (1996). Efficient integration of an intron RNA into double-stranded DNA by reverse splicing. Nature 381, 332-335.

Yanisch-Perron, C., Vieira, J. \& Messing, J. (1985). Improved M13 phage cloning vectors and host strains: nucleotide sequences of the M13mp18 and pUC19 vectors. Gene 33, 103-119.

Zimmerly, S., Guo, H., Perlman, P. S. \& Lambowitz, A. M. (1995). Group II intron mobility occurs by target DNA-primed reverse transcription. Cell 82, 545-554.

Received 10 January 1997; revised 18 March 1997; accepted 24 March 1997. 